\title{
SUCCESS FACTORS OF COLLABORATION IN THE CONTEXT OF DEVOPS
}

\author{
Michiel van Belzen, Dave de Kruijff and Jos Trienekens \\ Open University, The Netherlands
}

\begin{abstract}
Context: Collaboration is an important aspect of DevOps. However, researchers continue to report problems with collaboration between development and operations.

Objective: We aim to contribute to a better understanding of collaboration in the context of DevOps, especially to aid in adopting DevOps.

Method: We conducted a literature review on collaboration and corresponding success factors. For practice we classified the factors into factors influencing the likelihood of collaboration and factors influencing the performance of collaboration, to aid in the adoption of DevOps. We will validate the factors of collaboration in a DevOps context using an inductive approach, i.e. semi-structured interviews and document studies.

Results: We developed an initial framework of success factors and classified the found success factors. Subsequently we conducted two interviews. We learned that most factors are considered as important, however few factors could be confirmed and no more factors are added. We will interview the other respondents to prove the applicability of the framework. Which may identify promising avenues for further development of the framework.

Conclusions: This is study is not finalized yet, therefore we cannot fully answer the main research question.
\end{abstract}

\section{KEYWORDS}

DevOps, Adoption, Success Factors, Collaboration, Performance

\section{INTRODUCTION}

Organizations that can release software early and with a high frequency have a higher capability to compete in the market (Erich, Amrit, \& Daneva, 2017). Software producers need to deliver products and new features to customers as fast as they can (Colomo-Palacios, Fernandes, Soto-Acosta, \& Larrucea, 2018). The notion of software development agility (i.e. a software team's ability to efficiently and effectively respond to user requirement changes) is at the heart of agile development approaches (Lee \& Xia, 2010). At the same time it is important to be aware of drawbacks using incremental and agile practices, which are mainly related to increased complexity when scaling agile (Petersen \& Wohlin, 2009). DevOps, a compound of "development" and "operations," is a software development and delivery approach designed for high velocity (Sebastian et al., 2017). Companies are building continuous delivery (i.e., DevOps) into their digital services backbones to facilitate speed (Ross et al., 2016). DevOps adoption proves able to improve cycle times and quality (Colomo-Palacios et al., 2018). It appears that as, over time, DevOps capabilities (e.g. high velocity of software delivery and quality of IT services) will become a competitive necessity (Sebastian et al., 2017), it becomes important to know what DevOps is. However DevOps is not a precisely defined concept, organizations have to find their own way of implementing it which might slow down the rate of adoption (Erich et al., 2017). Moreover the authors did not found any quantitative data to show the effectiveness of DevOps. Erich et al (2017) consider DevOps as an interaction between development and operations personnel. Also other researchers (Claps, Berntsson Svensson, \& Aurum, 2015; Ebert, Gallardo, Hernantes, \& Serrano, 2016; Hüttermann, 2012; Wiedemann, 2018) consider DevOps as a set of practices that advocate the collaboration between software developers and IT operations, where the aim is to shorten the feedback loop while aligning the goals of both the development and IT operations departments. IS development and IT operations have to pursue the objective of establishing a relationship that ensures that high-quality IT services are being delivered to the business (Iden, Tessem, \& Paivarinta, 2012). IS development and IT operations in practice have to cooperate effectively on a number of topics and activities during a system 
development project (Iden et al., 2012). Thus it appears that collaboration is an important aspect of DevOps. However, researchers continue to report problems with collaboration between development and operations, e.g. poor communication (Iden et al., 2012; Lwakatare, Kuvaja, \& Oivo, 2015), cultural and organizational gaps (Wettinger, Breitenbücher, Falkenthal, \& Leymann, 2017), knowledge boundaries (Colomo-Palacios et al., 2018; Nielsen, Winkler, \& Norbjerg, 2017) and overcoming the Dev versus Ops mentality and Dev and Ops toolset clashes (Ghantous \& Gill, 2017). Experts with long and relevant industry experience agree that they do not cooperate effectively in development projects (Iden, Tessem, \& Päivärinta, 2011). Thus the topic of integrated corporate functions (e.g. DevOps) appear to be especially relevant (Rodríguez et al., 2017). To aid in adopting DevOps (De Feijter, Overbeek, Van Vliet, Jagroep, \& Brinkkemper, 2018) propose a DevOps competence model and a DevOps maturity model. However the case study was conducted in one organization, which poses a limitation on the generalizability of the case study results. And it is not clear whether all respondents were real DevOps experts.

Therefore we aim to contribute to a better understanding of collaboration in the context of DevOps, especially to aid in adopting DevOps. As existing literature has paid little attention to different contexts and success factors of collaboration (Yoon, Lee, Yoon, \& Toulan, 2017), we focus on the identification of success factors of collaboration and subsequently validate them empirically in a DevOps context. Our main research question is: What is successful collaboration in the context of DevOps? The sub questions are: (SQ1) What is collaboration? (SQ2) What are critical success factors of collaboration? (SQ3) How are these factors addressed by DevOps? First we conducted a systematic literature review (Kitchenham et al., 2010) on collaboration and success factors of collaboration. These concepts are elaborated in chapter 2. Based on the findings we developed an initial framework and classified the success factors (chapter 3). Subsequently we conducted two interviews and learned that most factors are considered as important, however few factors could be confirmed. Chapter 4 reveals our plan to conduct more interviews and to prove the applicability of the framework.

\section{THEORETICAL BACKGROUND}

In a comprehensive study on collaboration, (Bedwell et al., 2012) define collaboration as "An evolving process whereby two or more social entities actively and reciprocally engage in joint activities aimed at achieving at least one shared goal". Collaboration cannot be treated as a hardened structure, a "done deal"-in theory or in practice (Mintzberg, Jorgensen, Dougherty, \& Westley, 1996). Other researchers define collaboration also as a joint effort towards a group goal, e.g. (Kolfschoten, de Vreede, Briggs, \& Sol, 2010). Collaborative success depends on willingness of its participants, therefore it has an intrinsic unpredictable element which makes it a complex activity or task (Kolfschoten et al., 2010). The authors consider collaboration as both a process and a system.

On a firm level technological collaboration in small and medium-sized firms can impact product- and process innovation, while vertical collaboration (with suppliers and clients) has the greatest impact on firm innovativeness (Nieto \& Santamaria, 2010). The impact of collaboration, in a DevOps context, on innovation is confirmed by scholars, e.g. DevOps lower barriers for immediate and continuous delivery of new services and features (Airaj, 2017). Systematic managing social interaction between developers and IT operations staff (Iden \& Bygstad, 2018) is another example. According to the authors this will lead to important business improvements, including improved quality of software in operation, improved IT service quality. However a clear performance measurement and regulation must be set to accelerate the process innovation through collaboration (Yoon et al., 2017).

Bedwell et al. (2012) developed an overarching theoretical framework based on the Input-MediatorOutput-Input-framework (Ilgen, Hollenbeck, Johnson, \& Jundt, 2005), which has been used to describe phenomena related to performance. They consider the individual/entity characteristics as inputs, whereas the output is labeled 'distal collaborative output' to signify the achievement of a shared goal that motivated the collaborative initiative. They also include mediators that comprise the collaborative performance cycle: cognitive and affective emergent states, defined as "properties of the team that are typically dynamic in nature and vary as a function of team context, inputs, processes, and outcomes" and collaborative behaviors. They emphasize that the emergent states also influence one another and reciprocally influence collaborative behaviors enacted during a collaborative performance episode. This creates essentially a feedback loop, which incorporates initial collaborative performance outcomes back into the collaborative cycle until the distal collaborative outcome is achieved. In addition to these inputs, mediators, and outputs, their collaborative framework considers the moderating impact of contextual factors. 
DevOps adoption drives a challenging cultural shift towards collaboration and knowledge-sharing between software development, quality control and operations (Colomo-Palacios et al., 2018). All effective collaborative efforts require varying levels of coordination, depending on task and the size of the entities involved (Bedwell et al., 2012). Tessem and Iden (2008) consider collaboration, coordination and co-decisions as forms of cooperation (Tessem \& Iden, 2008). However, Bedwell et al (2012) define cooperation as an attitude or predisposition held by the involved parties to be concerned about the overall collaborative goal rather than their own individual goal. They consider cooperation as a requirement for effective collaboration, not as a description of collaboration itself. Some authors (Iden \& Bygstad, 2018; Söderlund, 2011) consider cooperation and coordination as the two main problems that must be solved when personnel with different professional profiles and organisational affiliations are to interact in a project.

In the early stages of research on collaboration Mattessich \& Monsey (1992) review and summarize existing research literature on factors which influence the success of collaboration. They identified nineteen success factors and grouped them into six categories (which have no research significance according to the authors). They confirmed the factors in 2001 and add an additional factor: An appropriate pace of development (Mattessich, Murray-Close, \& Monsey, 2001). (Mohr \& Spekman, 1994) studied the relationship between a computer dealer and one of its suppliers (i.e., manufacturers) at which both partners have jointly aligned goals to accomplish mutually beneficial end (which we consider as collaboration). They found the key characteristics of successful vertical collaboration to be confidence, adaptation, devotion, quality of communication, degree of participation, and the methods of solving common problems. (Mintzberg et al., 1996) noted that the nature of a particular collaboration may depend on impinging factors, e.g. task and the goal, the parties involved, and its evolution over time. The contexts surrounding the performance situation influences collaborative inputs, processes, and outcomes (Bedwell et al., 2012). (Marek, Brock, \& Savla, 2015) examined for distinctiveness and comprehensiveness, all factors and categories found by Mattessich \& Monsey (1992) that were linked to coalition success, and confirmed the original six categories identified by Mattessich and Monsey (1992). They also generate additional ones, introducing seven interrelated factors: context, members, process and organization, communication, function, resources and leadership. De Feijter et al. (2018) noticed that the organization itself should be in place to perform work, i.e. interdisciplinary professionals should communicate, share knowledge, have trust and respect for one another, work in teams, and there should be release alignment (some form of alignment between internal and external dependencies in order to timely deploy software). Kotlarsky \& Oshri (2005) mentioned human-related issues/factors in the form of social ties, in particular rapport and transactive memory, and organizational mechanisms that create and maintain social ties between dispersed team members. Tsanos et al. (2014) identified comparable factors: trust, commitment, mutuality and reciprocity.

\section{TOWARDS A FRAMEWORK OF SUCCESS FACTORS FOR COLLABORATION}

We started with the work of (Mattessich \& Monsey, 1992) and (Mohr \& Spekman, 1994), which are well-known publications. And applied forward snowballing to search for further peer reviewed research (described in section 2) on this topic. We found additional success factors in (Marek et al., 2015; Patel, Pettitt, \& Wilson, 2012; Tsanos et al., 2014; Yoon et al., 2017). However, the search missed five relevant papers of which we were aware: (Bedwell et al., 2012; De Feijter et al., 2018; Kolfschoten et al., 2010; Kotlarsky \& Oshri, 2005; Lwakatare et al., 2015). We only found additional factors in Bedwell et al. (2012). We put all the found success factors into one table and add the corresponding definitions, which forms the basis of our framework.

To search for confirmation of the found success factors in a DevOps context, we conduct a systematic literature review (Kitchenham et al., 2010). We searched two digital libraries in December 2018: Web of Science and Business Source Premier. All searches were based on title and the period between 2009 (the emerge of DevOps (Dornenburg, 2018; Hüttermann, 2012)) and 2018. For all the sources we used the following search string: (collaboration OR cooperation OR coordination) AND factor. We undertook an initial screening of the 554 papers found. The screening was based on excluding papers that were obviously irrelevant, duplicates, not written in English, not peer reviewed or not in the field of Business/Management or Computer Science. The remaining 81 papers were then assessed to identify papers that could be rejected based on abstract and title on the basis that they did not include success factors of collaboration between Development and Operations (DevOps). We found no other papers which confirmed the success factors in our initial framework. 
The next step we took was classification of the found factors. As our research goal is to aid in adopting DevOps, we would like to classify the found factors in line with the process of evolving collaboration. De Feijter et al. (2018) classify in their maturity model five focus areas (which are part of the perspective of culture and collaboration) gradually in terms of capabilities. I.e. capabilities in levels 1 to 5 mention a situation where an organization is not yet adopting DevOps, capabilities in levels 5 and 6 mention a situation transitioning to a DevOps situation and capabilities in levels 5 to 10 mention a situation in which DevOps is already adopted to a more mature extent. However the success factors we found were of a different abstraction level and not fine grained. In addition the maturity model of De Feijter et al. (2018) does not take into account all the factors we found. Therefore we classify the found success factors into a more coarse way: factors influencing the likelihood of collaboration and factors influencing the performance of collaboration, which is a widely used classification method (Yoon et al., 2017). Yoon et al. (2017) add five success factors to the planning stage perspective, which we consider as success factors influencing the likelihood of collaboration (table 1). Tsanos et al. (2014) identified four factors that are recurrently mentioned as antecedents of collaboration: trust, commitment, mutuality and reciprocity. The authors mentioned that complicated pairings of concepts exist (e.g. trust and commitment). These factors are also part of the definition of collaboration of (Bedwell et al., 2012). Although trust and commitment are not explicitly mentioned, we consider them as prerequisites of mutuality and reciprocity. Therefore we add the four factors found by (Tsanos et al., 2014) to table 1. All other found success factors will be considered as factors influencing the performance of collaboration. Comparable success factors will obtain the same classification. We applied this classification in order to organize the analysis of the empirical data (e.g. new factors) as well.

Table 1. Success Factors influencing the likelihood of Collaboration (Tsanos et al., 2014; Yoon et al., 2017)

\begin{tabular}{|c|c|}
\hline Success factor & Content and operational definition \\
\hline Setting of clear goals & $\begin{array}{l}\text { - Setting of clear goals at the planning stage. } \\
\text { - Supplementary purposes. }\end{array}$ \\
\hline Distribution regulation for collaboration results & $\begin{array}{l}\text { Prescribe issues related to distribution in advance, and prevent technical } \\
\text { knowhow from leaking out. }\end{array}$ \\
\hline Methods of solving common issues & $\begin{array}{l}\text { Refrain from using harsh methods such as persuasion, domination and } \\
\text { arbitration to solve conflicts. }\end{array}$ \\
\hline Governance: clear role-setting & Main agents and strategies about role-setting of collaboration. \\
\hline $\begin{array}{l}\text { Governance-defining performance measurement } \\
\text { methods }\end{array}$ & Main agents about methods to measure performance of collaboration. \\
\hline Trust & Professionals trust each other. \\
\hline Commitment & $\begin{array}{l}\text { The belief of a partner that the exchange is so important it merits the } \\
\text { maximum effort to maintain it. }\end{array}$ \\
\hline Mutuality & Belief about the inherent value of cooperating for mutual gain. \\
\hline Reciprocity & $\begin{array}{l}\text { Degree to which individuals expect cooperative action (as opposed to } \\
\text { forced interaction) within a relationship. }\end{array}$ \\
\hline
\end{tabular}

This leads us to the theoretical framework with success factors of collaboration (table 2). If a respondent confirmed a success factor we added to table 2 examples of practices and if applicable how they measure collaboration.

Table 2. Theoretical Framework with Success Factors of Collaboration

\begin{tabular}{llll}
\hline Classification & Success factor & Operational definition & Confirmation \\
\hline $\begin{array}{l}\text { Success } \\
\text { factors } \\
\text { influencing } \\
\text { the }\end{array}$ & $\begin{array}{l}\text { Concrete attainable } \\
\text { goals and objectives }\end{array}$ & $\begin{array}{l}\text { Setting of clear goals (at the planning stage), supplementary } \\
\text { purposes (Patel et al., 2012; Yoon et al., 2017) and feasible } \\
\text { (Mattessich \& Monsey, 1992), based on key community } \\
\text { collaboration }\end{array}$ & - \\
& $\begin{array}{l}\text { Shared vision } \\
\text { issues, agreed upon (Marek et al., 2015). }\end{array}$ & $\begin{array}{l}\text { With clearly agreed upon mission, objectives and strategy. } \\
\text { May exist at the outset of collaboration or may develop in } \\
\text { time (Mattessich \& Monsey, 1992; Patel et al., 2012). }\end{array}$ & - \\
& Unique purpose & $\begin{array}{l}\text { Mission and goals or approach differ (at least in part) from } \\
\text { the mission and goals or approach of the member }\end{array}$ & - \\
& & $\begin{array}{l}\text { organizations (Mattessich \& Monsey, 1992) } \\
\text { Prescribe issues related to distribution in advance, and } \\
\text { prevent technical knowhow from leaking out (Yoon et al., }\end{array}$ & \\
& $\begin{array}{l}\text { Distribution } \\
\text { regulation for } \\
\text { collaboration results } \\
\text { Clear rules and }\end{array}$ & $\begin{array}{l}\text { 2017). } \\
\text { The need for clear rules and procedures in order to structure }\end{array}$ & -
\end{tabular}




\begin{tabular}{|c|c|c|c|}
\hline Classification & Success factor & Operational definition & $\mathrm{C}$ \\
\hline & procedures & $\begin{array}{l}\text { collaboration (Marek et al., 2015). The methods of solving } \\
\text { common problems (Mohr and Spekman, 1994). Error } \\
\text { management: the procedures to identify and manage errors } \\
\text { and violations (Patel et al., 2012). Refrain from using harsh } \\
\text { methods such as persuasion, domination and arbitration to } \\
\text { solve conflicts (Yoon et al., 2017). }\end{array}$ & \\
\hline & $\begin{array}{l}\text { Clear roles and } \\
\text { responsibilities }\end{array}$ & $\begin{array}{l}\text { The need for roles and responsibilities in order to structure } \\
\text { collaboration (Marek et al., 2015; Patel et al., 2012). Main } \\
\text { agents and strategies about role-setting of collaboration } \\
\text { (Yoon et al., 2017). }\end{array}$ & \\
\hline & $\begin{array}{l}\text { Governance-defining } \\
\text { performance } \\
\text { measurement } \\
\text { methods }\end{array}$ & $\begin{array}{l}\text { Main agents about methods to measure performance of } \\
\text { collaboration (Yoon et al., 2017). Performance relevant to } \\
\text { collaborative working includes: keeping to project budgets } \\
\text { and deadlines, profits, time saved, meeting or improving } \\
\text { required quantity and quality of product/service, improving } \\
\text { work processes, innovation, achieving goals, meeting } \\
\text { requirements, improving relationships, extending } \\
\text { professional networks, generating new business, learning, } \\
\text { individual and team satisfaction and wellbeing, improving } \\
\text { trust and commitment, reducing errors, high level of safety, } \\
\text { low levels of absenteeism and staff turnover (Patel et al., } \\
\text { 2012). }\end{array}$ & \\
\hline & $\begin{array}{l}\text { Mutual respect, } \\
\text { understanding, and } \\
\text { trust (social ties). } \\
\text { Conflict. }\end{array}$ & $\begin{array}{l}\text { Understanding and respect for each other and their respective } \\
\text { organizations: how they operate, their cultural norms and } \\
\text { values, limitations, and expectations (Kolfschoten et al., } \\
\text { 2010; Mattessich \& Monsey, 1992), confidence (Mohr \& } \\
\text { Spekman, 1994), professionals trust each other, respect (De } \\
\text { Feijter et al., 2018; Tsanos et al., 2014) and human-related } \\
\text { issues (Kotlarsky \& Oshri, 2005). Conflict (Patel et al., } \\
\text { 2012). }\end{array}$ & \\
\hline & $\begin{array}{l}\text { Members see } \\
\text { collaboration as in } \\
\text { their self-interest }\end{array}$ & $\begin{array}{l}\text { Mindset where collaboration is seen as contribution to the } \\
\text { quality of tasks and outcomes (Marek et al., 2015; Mattessich } \\
\& \text { Monsey, 1992). Commitment, i.e. the belief of a partner } \\
\text { that the exchange is so important it merits the maximum } \\
\text { effort to maintain it (Tsanos et al., 2014). }\end{array}$ & \\
\hline & $\begin{array}{l}\text { Members share a } \\
\text { stake in both process } \\
\text { and outcome }\end{array}$ & $\begin{array}{l}\text { Members feel 'ownership' of the way the group works and } \\
\text { the results or product of its work (Mattessich \& Monsey, } \\
\text { 1992). Devotion (Mohr \& Spekman, 1994). Incentives which } \\
\text { emphasize team goals rather than individual goals (Patel et } \\
\text { al., 2012). }\end{array}$ & \\
\hline & Mutuality & $\begin{array}{l}\text { Belief about the inherent value of cooperating for mutual gain } \\
\text { (Tsanos et al., 2014). }\end{array}$ & \\
\hline & (Shared) resources & $\begin{array}{l}\text { Reciprocity, i.e. the degree to which individuals expect } \\
\text { cooperative action (as opposed to forced interaction) within a } \\
\text { relationship (Tsanos et al., 2014), sharing time, effort, } \\
\text { knowledge, interaction channels, physical resources } \\
\text { (Kolfschoten et al., 2010)(Marek et al., 2015), monitoring } \\
\text { information (Lwakatare et al., 2015). Resources, training, } \\
\text { team building, relationships, shared knowledge/awareness, } \\
\text { common ground, constraints (Patel et al., 2012). }\end{array}$ & \\
\hline
\end{tabular}

Success History

factors

influencing

the Leadership

performance

of

collaboration Political/social climate favorable
Exists in the community, offers partners an understanding of, and trust in, the collaboration process (Mattessich \& Monsey, 1992).

The collaborative group is perceived as a leader, at least related to the goals and activities it intends to accomplish (Mattessich \& Monsey, 1992).

Stakeholders support (or at least do not oppose) the mission of the collaborative group (Mattessich \& Monsey, 1992).
Confirmation

Developers are higher educated, the perception of developers on Ops is that they only execute and maintain. There is still a large gap between operations and development, they are not seen as one team at the moment.

Lack of social skills, mindset and background are obstacles as well as hesitation of older employees.

Feedback received by the software integration team is more useful and detailed. Have the status of being the specialist in this field.

Hierarchic organization is an obstacle for other 


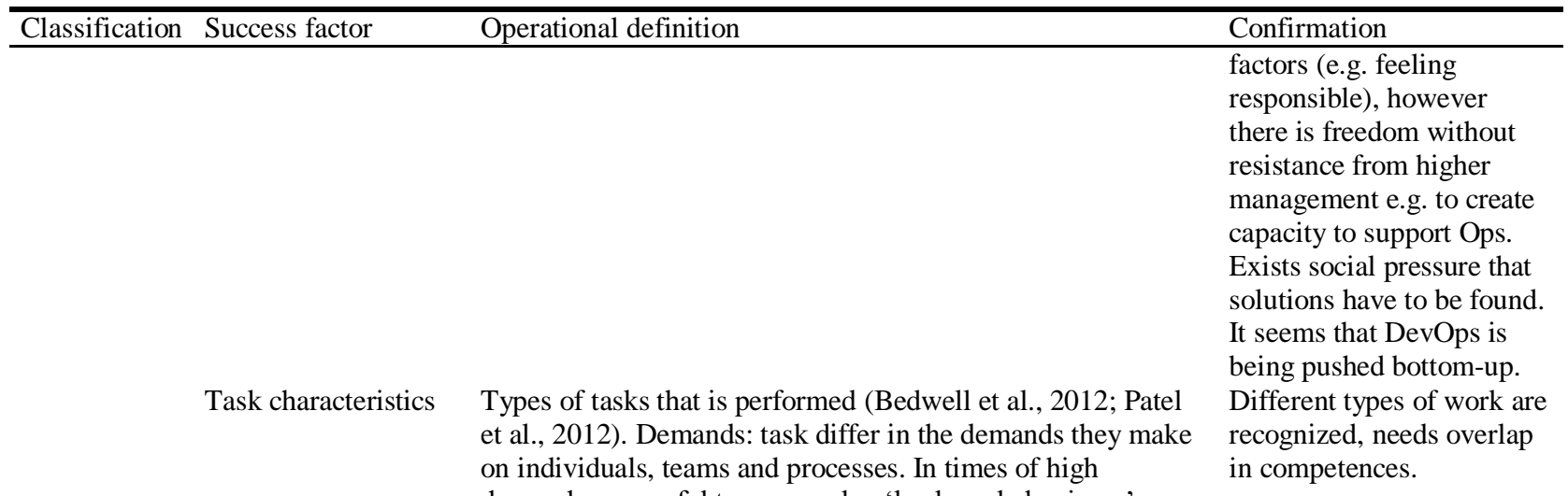

Environmental characteristics

Temporal characteristics

Structural characteristics

Ability to compromise

Appropriate crosssection of members

Members view the benefits of collaboration as outweighing the costs Multiple layers of decision-making and participation

Flexibility on individuals, teams and processes. In times of high demand, successful teams employ 'back-up behaviours' (Patel et al., 2012).

Degree of risk prevalent in the environment, the level of autonomy that members have in their work, stressors (e.g. dangerous work conditions, or uncertainty), different cultures which result in a different manner to approach the collaboration (Bedwell et al., 2012), culture, environment and business climate (Patel et al., 2012).

Including team lifespan, performance episode duration, performance episode frequency, and continuity of membership (Bedwell et al., 2012). Time limits, cycles of activity, work rhythms, events when a team is first formed and how their goals and tasks are communicated and discussed. Temporary versus long-term teams, individuals' power sources may vary over time (e.g. with age, experience, time on the job and by expanding their professional and personal networks) and can alter interpersonal dynamics and their capacity to influence the context within which collaboration takes place (Patel et al., 2012).

Including structure of leadership, communication structure and division of work and roles among members, distribution (physical and temporal) of members (Bedwell et al., 2012), organizational structure and task structure (Patel et al., 2012). Coordination (Bedwell et al., 2012) which involves goal setting, managing and integrating people and information etc. (Patel et al., 2012).

Partners are able to compromise, since the many decisions within a collaborative effort can not possibly fit the preferences of every member perfectly (Mattessich \& Monsey, 1992). Group decision making (Patel et al., 2012). Representatives are included from each segment of the community who will be affected by its activities (De Feijter et al., 2018; Mattessich \& Monsey, 1992). Team composition, skills, experience, psychological factors, wellbeing (Patel et al., 2012).

Believe that the benefits of collaboration will offset costs such as loss of autonomy and 'turf' (Mattessich \& Monsey, 1992).

Every management level within each organization participates in decision-making (Mattessich \& Monsey, 1992), degree of participation (Mohr \& Spekman, 1994; Patel et al., 2012), release alignment (De Feijter et al., 2018). Open to varied ways of organizing and accomplishing work (Mattessich \& Monsey, 1992).
Freedom without resistance from higher management e.g. to create capacity to support Ops.

Internal Ops and Dev are closely situated, which reduces the complexity of communication. The communication with external Ops is a bit more difficult.
Some teams continuously focus on goals they need to reach. 


\begin{tabular}{|c|c|c|c|}
\hline Classification & Success factor & Operational definition & Confirmation \\
\hline & Adaptability & $\begin{array}{l}\text { Ability to sustain itself in the midst of major changes, even if } \\
\text { it needs to change some major goals, members, etc., in order } \\
\text { to deal with changing conditions (Mattessich \& Monsey, } \\
\text { 1992), adaptation (Mohr \& Spekman, 1994). }\end{array}$ & $\begin{array}{l}\text { Employees quickly adopt } \\
\text { new technology in order to } \\
\text { deal with changing } \\
\text { conditions. }\end{array}$ \\
\hline & $\begin{array}{l}\text { Appropriate pace of } \\
\text { development }\end{array}$ & $\begin{array}{l}\text { The structure, resources, and activities of the collaborative } \\
\text { group change over time to meet the needs of the group } \\
\text { without overwhelming its capacity, at each point throughout } \\
\text { the initiative (Mattessich et al., 2001). }\end{array}$ & \\
\hline & Knowledge & The sharing of knowledge (as a resource) (De Feijter et al., & Knowledge is partially \\
\hline & Management & $\begin{array}{l}\text { 2018; Kotlarsky \& Oshri, 2005; Patel et al., 2012). Training, } \\
\text { learning, skills and team building (Patel et al., 2012). }\end{array}$ & $\begin{array}{l}\text { shared by a shared } \\
\text { platform. }\end{array}$ \\
\hline & $\begin{array}{l}\text { Formal and informal } \\
\text { communication }\end{array}$ & $\begin{array}{l}\text { Channels of communication and information flows, personal } \\
\text { connections (De Feijter et al., 2018; Kolfschoten et al., 2010; } \\
\text { Mattessich \& Monsey, 1992; Patel et al., 2012), networks } \\
\text { (Patel et al., 2012). }\end{array}$ & $\begin{array}{l}\text { Formal communication } \\
\text { mainly focus on risk } \\
\text { management. }\end{array}$ \\
\hline & $\begin{array}{l}\text { Open, frequent and } \\
\text { clear communication }\end{array}$ & $\begin{array}{l}\text { Frequent, open and clear interactions, conveying all } \\
\text { necessary information (Mattessich \& Monsey, 1992; Patel et } \\
\text { al., 2012). Set meeting times (Marek et al., 2015), quality (De } \\
\text { Feijter et al., 2018; Mohr \& Spekman, 1994). Group } \\
\text { processes (social and psychological interactions) (Patel et al., } \\
\text { 2012). }\end{array}$ & - \\
\hline & Sufficient funds & $\begin{array}{l}\text { Adequate, consistent financial base (Marek et al., 2015; } \\
\text { Mattessich \& Monsey, 1992) and resources (Patel et al., } \\
\text { 2012). }\end{array}$ & $\begin{array}{l}\text { Budget cuts in recent years } \\
\text { put engineering research } \\
\text { below a critical level. }\end{array}$ \\
\hline & $\begin{array}{l}\text { Skilled } \\
\text { leader/Management }\end{array}$ & $\begin{array}{l}\text { Convener with organizing and interpersonal skills, carries out } \\
\text { the role with fairness, is granted respect or legitimacy } \\
\text { (Mattessich \& Monsey, 1992). Support from management } \\
\text { e.g. providing clear direction, guidance, inspiration of } \\
\text { collaborative project management (Patel et al., 2012). }\end{array}$ & - \\
\hline & Tools & $\begin{array}{l}\text { Technologies for collaborating, e.g. email, conferencing, } \\
\text { scheduling tools and knowledge management tools (Patel et } \\
\text { al., 2012). }\end{array}$ & - \\
\hline
\end{tabular}

To validate this framework in a DevOps context, we will use an inductive approach, i.e. carrying out semi-structured interviews and document studies (cross sectional). This approach enables us to achieve depth, elaboration and soundness (Verschuren \& Doorewaard, 2010), which is important as we aim to contribute to a better understanding of collaboration in the context of DevOps. We will conduct approximately twelve interviews in two IT Service Provider organisations (ISP's) which serve 12,000 (ISP1) respectively 60,000 (ISP2) employees. Both have different maturity levels of DevOps implementation, ISP1 experience DevOps for one year, ISP2 have several years of experience with DevOps. We will interview managers of Development-, Operations- or DevOps-teams, advisors and managers (on tactic/strategic levels) which are closely involved at the introduction and evolvement of DevOps. We ask them whether they recognize the success factors and if they know additional factors. To obtain more soundness and to explore if we can find any (quantitative) data to show the effectiveness of DevOps (to close the gap mentioned by Erich et al. (2017)), we ask for examples based on own experiences and facts and ask how they measure success. Collaboration performance measurement can be broadly classified into quantitative (e.g. the degree of improvement in productivity and profitability) and qualitative (e.g. perceived satisfaction, status of goal accomplishment) performance (Yoon et al., 2017). Bedwell et al. (2012) mentioned six behaviors to measure collaborative performance: adaptive, extra-role, information processing, leadership, sensemaking and task execution. We consider these six behaviors as less abstract for our respondents, therefore we will use them as examples to support the question about how they measure success. But we will ask the respondents whether they measure any additional quantitative or qualitative performance aspects. After making an appointment with the respondents and before the interviews started, we share the definition of collaboration, the six behaviors of Bedwell et al. (2012) and the found success factors (table 2), and we share a short summary of the research project with the respondents.

At this moment we conducted two semi-structured interviews. We started with a pilot interview at ISP1 to test our interview guide (Yin, 2012). We learned that we have to add an explanation to the six behaviors of Bedwell et al. (2012). No more improvements were necessary. After the pilot interview we conducted the 
second interview at ISP1. Although the respondents recognized the importance of several factors, they could not confirm them in terms of how the factors are measured (indicated in table 2). In addition they mentioned no other/new success factors. We will interview the other respondents in the coming months. Each respondent will have the opportunity to amend the transcription of the interview before we analyse the data by open coding.

\section{CONCLUSIONS AND FUTURE WORK}

We conducted a literature review on collaboration and developed an initial framework of success factors. To aid in the adoption of DevOps, we classified the factors into factors influencing the likelihood of collaboration and factors influencing the performance of collaboration. Subsequently we conducted two interviews. We learned that most factors are considered as important, however few factors could be confirmed and no more factors are added. Thus the preliminary results confirmed in part the initial framework (table 2).

We will interview the other respondents to prove the applicability of the framework. Which may identify promising avenues for further of the framework, e.g. distinctions between factors in terms of different maturity levels of DevOps implementation and possible ranking (regarding the impact) of success factors. Regarding the quality of the case study we will address internal-, construct- and external validity and reliability aspects.

\section{REFERENCES}

Airaj, M. (2017). Enable cloud DevOps approach for industry and higher education: Enable cloud DevOps approach for industry and higher education. Concurrency and Computation: Practice and Experience, 29(5), e3937. https://doi.org/10.1002/cpe.3937

Bedwell, W. L., Wildman, J. L., DiazGranados, D., Salazar, M., Kramer, W. S., \& Salas, E. (2012). Collaboration at work: An integrative multilevel conceptualization. Human Resource Management Review, 22(2), 128-145. https://doi.org/10.1016/j.hrmr.2011.11.007

Claps, G. G., Berntsson Svensson, R., \& Aurum, A. (2015). On the journey to continuous deployment: Technical and social challenges along the way. Information and Software Technology, 57, 21-31. https://doi.org/10.1016/j.infsof.2014.07.009

Colomo-Palacios, R., Fernandes, E., Soto-Acosta, P., \& Larrucea, X. (2018). A case analysis of enabling continuous software deployment through knowledge management. International Journal of Information Management, 40, 186-189. https://doi.org/10.1016/j.ijinfomgt.2017.11.005

De Feijter, R., Overbeek, S., Van Vliet, R., Jagroep, E., \& Brinkkemper, S. (2018). DevOps Competences and Maturity for Software Producing Organizations. In J. Gulden, I. Reinhartz-Berger, R. Schmidt, S. Guerreiro, W. Guédria, \& P. Bera (Eds.), Enterprise, Business-Process and Information Systems Modeling (Vol. 318, pp. 244-259). Cham: Springer International Publishing. https://doi.org/10.1007/978-3-319-91704-7_16

Dornenburg, E. (2018). The Path to DevOps. IEEE Software, 35(5), 71-75. https://doi.org/10.1109/MS.2018.290110337

Ebert, C., Gallardo, G., Hernantes, J., \& Serrano, N. (2016). DevOps. IEEE Software, 33(3), 94-100. https://doi.org/10.1109/MS.2016.68

Erich, F. M. A., Amrit, C., \& Daneva, M. (2017). A qualitative study of DevOps usage in practice: A Qualitative Study of DevOps Usage in Practice. Journal of Software: Evolution and Process, 29(6), e1885. https://doi.org/10.1002/smr.1885

Ghantous, G. B., \& Gill, A. (2017). DevOps: Concepts, Practices, Tools, Benefits and Challenges. PACIS 2017 Proceedings. Retrieved from http://aisel.aisnet.org/pacis2017/96

Hüttermann, M. (2012). DevOps for developers. Apress.

Iden, J., \& Bygstad, B. (2018). The social interaction of developers and IT operations staff in software development projects. International Journal of Project Management, 36(3), 485-497. https://doi.org/10.1016/j.ijproman.2017.12.001

Iden, J., Tessem, B., \& Päivärinta, T. (2011). Problems in the interplay of development and IT operations in system development projects: A Delphi study of Norwegian IT experts. Information and Software Technology, 53(4), 394-406.

Iden, J., Tessem, B., \& Paivarinta, T. (2012). IS development/IT operations alignment in system development projects: a multi-method research. International Journal of Business Information Systems, 11(3), 343-359.

Ilgen, D. R., Hollenbeck, J. R., Johnson, M., \& Jundt, D. (2005). Teams in Organizations: From Input-Process-Output Models to IMOI Models. Annual Review of Psychology, 56(1), 517-543. https://doi.org/10.1146/annurev.psych.56.091103.070250 
Kitchenham, B., Pretorius, R., Budgen, D., Pearl Brereton, O., Turner, M., Niazi, M., \& Linkman, S. (2010). Systematic literature reviews in software engineering - A tertiary study. Information and Software Technology, 52(8), $792-805$. https://doi.org/10.1016/j.infsof.2010.03.006

Kolfschoten, G. L., de Vreede, G.-J., Briggs, R. O., \& Sol, H. G. (2010). Collaboration ‘Engineerability'. Group Decision and Negotiation, 19(3), 301-321. https://doi.org/10.1007/s10726-010-9192-8

Kotlarsky, J., \& Oshri, I. (2005). Social ties, knowledge sharing and successful collaboration in globally distributed system development projects. European Journal of Information Systems, 14(1), 37-48. https://doi.org/10.1057/palgrave.ejis.3000520

Lee, G., \& Xia, W. (2010). Toward Agile: An Integrated Analysis of Quantitative and Qualitative Field Data. MIS Q., 34(1), 87-114.

Lwakatare, L. E., Kuvaja, P., \& Oivo, M. (2015). Dimensions of devops. In International Conference on Agile Software Development (pp. 212-217). Springer.

Marek, L. I., Brock, D.-J. P., \& Savla, J. (2015). Evaluating Collaboration for Effectiveness: Conceptualization and Measurement. American Journal of Evaluation, 36(1), 67-85. https://doi.org/10.1177/1098214014531068

Mattessich, P. W., \& Monsey, B. R. (1992). Collaboration--what makes it work: a review of research literature on factors influencing successful collaboration. St. Paul, Minn: Amherst H. Wilder Foundation.

Mattessich, P. W., Murray-Close, M., \& Monsey, B. R. (2001). Collaboration What Makes It Work (Vol. 2nd.). Saint Paul, MN: Fieldstone Alliance.

Mintzberg, H., Jorgensen, J., Dougherty, D., \& Westley, F. (1996). Some surprising things about collaborationKnowing how people connect makes it work better. Organizational Dynamics, 25(1), 60-71. https://doi.org/10.1016/S0090-2616(96)90041-8

Mohr, J., \& Spekman, R. (1994). Characteristics of partnership success: Partnership attributes, communication behavior, and conflict resolution techniques. Strategic Management Journal, 15(2), 135-152. https://doi.org/10.1002/smj.4250150205

Nielsen, P. A., Winkler, T. J., \& Norbjerg, J. (2017). Closing the IT Development-Operations gap: The DevOps knowledge sharing framework. 16th International Conference on Perspectives in Business Informatics Research. BIR 2017. CEUR

Nieto, M. J., \& Santamaria, L. (2010). Technological Collaboration: Bridging the Innovation Gap between Small and Large Firms. Journal of Small Business Management, 48(1), 44-69. https://doi.org/10.1111/j.1540627X.2009.00286.X

Patel, H., Pettitt, M., \& Wilson, J. R. (2012). Factors of collaborative working: A framework for a collaboration model. Applied Ergonomics, 43(1), 1-26. https://doi.org/10.1016/j.apergo.2011.04.009

Petersen, K., \& Wohlin, C. (2009). A comparison of issues and advantages in agile and incremental development between state of the art and an industrial case. Journal of Systems and Software, 82(9), 1479-1490. https://doi.org/10.1016/j.jss.2009.03.036

Rodríguez, P., Haghighatkhah, A., Lwakatare, L. E., Teppola, S., Suomalainen, T., Eskeli, J., ... Oivo, M. (2017). Continuous deployment of software intensive products and services: A systematic mapping study. Journal of Systems and Software, 123, 263-291. https://doi.org/10.1016/j.jss.2015.12.015

Ross, J. W., Sebastian, I. M., Beath, C., Mocker, M., Moloney, K. G., \& Fonstad, N. O. (2016). Designing and Executing Digital Strategies (pp. 1-17). Presented at the Thirty Seventh International Conference on Information Systems, Dublin.

Sebastian, I. M., Ross, J. W., Beath, C., Mocker, M., Moloney, K. G., \& Fonstad, N. O. (2017). How Big Old Companies Navigate Digital Transformation. MIS Quarterly Executive, 16(3), 197-213.

Söderlund, J. (2011). Theoretical Foundations of Project Management. Oxford University Press. https://doi.org/10.1093/oxfordhb/9780199563142.003.0003

Tessem, B., \& Iden, J. (2008). Cooperation between developers and operations in software engineering projects (pp. 105-108). ACM Press. https://doi.org/10.1145/1370114.1370141

Tsanos, C. S., Zografos, K. G., \& Harrison, A. (2014). Developing a conceptual model for examining the supply chain relationships between behavioural antecedents of collaboration, integration and performance. The International Journal of Logistics Management, 25(3), 418-462. https://doi.org/10.1108/IJLM-02-2012-0005

Verschuren, P., \& Doorewaard, H. (2010). Designing a Research Project (2nd edition). Eleven International Publishing.

Wettinger, J., Breitenbücher, U., Falkenthal, M., \& Leymann, F. (2017). Collaborative gathering and continuous delivery of DevOps solutions through repositories. Computer Science - Research and Development, 32(3-4), 281-290. https://doi.org/10.1007/s00450-016-0338-z

Wiedemann, A. (2018). IT Governance Mechanisms for DevOps Teams - How Incumbent Companies Achieve Competitive Advantages. Presented at the Hawaii International Conference on System Sciences. https://doi.org/10.24251/HICSS.2018.617

Yin, R. K. (2012). Applications of case study research (3rd ed). Thousand Oaks, Calif: SAGE.

Yoon, C., Lee, K., Yoon, B., \& Toulan, O. (2017). Typology and Success Factors of Collaboration for Sustainable Growth in the IT Service Industry. Sustainability, 9(11), 2017. https://doi.org/10.3390/su9112017 